\title{
The Exploration of Metallic Deposits Using Satellite Image Processing in the Parwan-Panjsher Area, Afghanistan ${ }^{+}$
}

\author{
Mahdi Khalaj ${ }^{1}$, Ziba Karimi ${ }^{2}$ and Mohsen Rabbani ${ }^{1, *}$ \\ 1 Mining Department, Omran Geotechnic Company (OGC), Kabul 1001, Afghanistan; \\ Miningdepartment@ogc.af \\ 2 Ministry of Mines and Petroleum, Kabul 1001, Afghanistan; Zibakarimi513@gmail.com \\ * Correspondence: Mining@ogc.af \\ + Presented at the 2nd International Electronic Conference on Mineral Science, 1-15 March 2021; Available \\ online: https://iecms2021.sciforum.net/.
}

Citation: Khalaj, M.; Karimi, Z.; Rabbani, M. The Exploration of Metallic Deposits Using Satellite Image Processing in the ParwanPanjsher Area, Afghanistan. Environ. Sci. Proc. 2021, 6, 30. https://doi.org/ 10.3390/iecms2021-09354

Academic Editor: Paul Sylvester

Published: 25 February 2021

Publisher's Note: MDPI stays neutral with regard to jurisdictional claims in published maps and institutional affiliations.

Copyright: (c) 2021 by the authors. Licensee MDPI, Basel, Switzerland. This article is an open access article distributed under the terms and conditions of the Creative Commons Attribution (CC BY) license (http://creativecommons.org/licenses /by/4.0/).

\begin{abstract}
Unique tectonic features have resulted in diverse metallic and non-metallic mineralization in Afghanistan. Hence, this paper is focused on the development of exploration and mineral resource data in Afghanistan. The study area is located in the western Hindu Kush tract and on the northern verge of the Hari Rud-Panjsher fault, Afghanistan, which mainly associates with the western Hindu Kush and Badakhshan plutonic belts. The rock units include crystalline limestones and diabase formed during the Paleozoic era and Triassic period. The aim of this study was to employ Remote Sensing (RS) methods by using the Landsat- 8 satellite and ASTER sensor to spot iron and copper mineralization zones in the Parwan-Panjsher area. Therefore, Band Composition, Principal Component Analysis (PCA), and Band Ratio were applied to identify the iron oxide minerals. The detected area provided by satellite images had very good conformability with the results of field studies. Furthermore, mineralization of carbonate host-rock iron and $\mathrm{Fe}-\mathrm{Cu}-(\mathrm{Au})$ skarn were observed during the field surveys. Hematite-Magnetite, Chalcopyrite, and pyrite mineralization have resulted from the injection of various diabase subvolcanic into carbonate units. Additionally, high heat flow has caused widespread marble formation in the area. The results were supported by microscopic and geochemical studies.
\end{abstract}

Keywords: Afghanistan; Parwan-Panjsher; Fe-Cu-(Au) skarn; remote sensing; exploration; principal component analysis (PCA)

\section{Introduction}

The mineralization process in Afghanistan comprises a wide range of metallic and non-metallic deposits with a high level of value, volume, and grade [1,2]. Although there is a wide range of mineral resources in Afghanistan, almost all of these mineral deposits have not been systematically explored or successfully mined [3]. There are many techniques for mineral exploration in which two common techniques are Remote Sensing (RS) images and field studies [4]. In general, RS is an effective tool to collect raster data and images, a rapid technique to detect distinctive adsorption features of hydrothermal alteration ore minerals, and a reliable method to provide geological mapping [5].

After defining the problems, the purpose of this study was explained to develop geological exploration information about iron mineralization in Afghanistan by employing the RS technique and a field survey. Therefore, an accessible study area located on the northern verge of the Hari Rud-Panjsher fault was selected because this AOI is the largest iron ore deposit in the central iron belt of Afghanistan (Haji Gak-PanjsherBadakhshan iron belt) [6]. To characterize the geological data regarding this unstudied area, available data derived from previous studies about Parwan-Panjsher AOI were collected and the distribution of iron oxide was identified by processing of Landsat and 
ASTER Images [7-9]. Additionally, to confirm results, a field survey and rock sampling were performed, and XRF analyses, determination of the grade of elements, and studies of polished sections were carried out on some collected samples from AOI.

\subsection{Regional Geology}

Afghanistan has a complex geology with rocks revealing every geologic age from Archean to the present. In other words, there is a comprehensive of varied crustal blocks separated by major fault zones in which each block is characterized by a different history and metallogenic feature. The occurrences and iron deposits are present in the Hari RudPanjsher Zone (the central part Afghanistan) and along $600 \mathrm{~km}$ from east to west. The host rock types related to these AOI are Proterozoic metamorphic carbonate and volcanic rocks. Many of the iron deposits and the occurrences are hematite-magnetite, such as Haji Gak iron ore deposit, the largest hematite-magnetite deposit in the Middle East [10] (Figure 1a).

The Middle Paleozoic metamorphic rocks showed by a Silurian-Lower Carboniferous marble and Lower Carboniferous and Upper Carboniferous-Lower Permian terrigenous schist are the main geological features of the Panjsher Valley.

The AOI consists of fragmented structures and various fault blocks, and its largest area mainly includes mélange zones, which is on the verge of the main faults, with composition of carbonate rocks, tuffs, basaltic units, siliceous rocks and small granitic apophyses (Figure 1b).

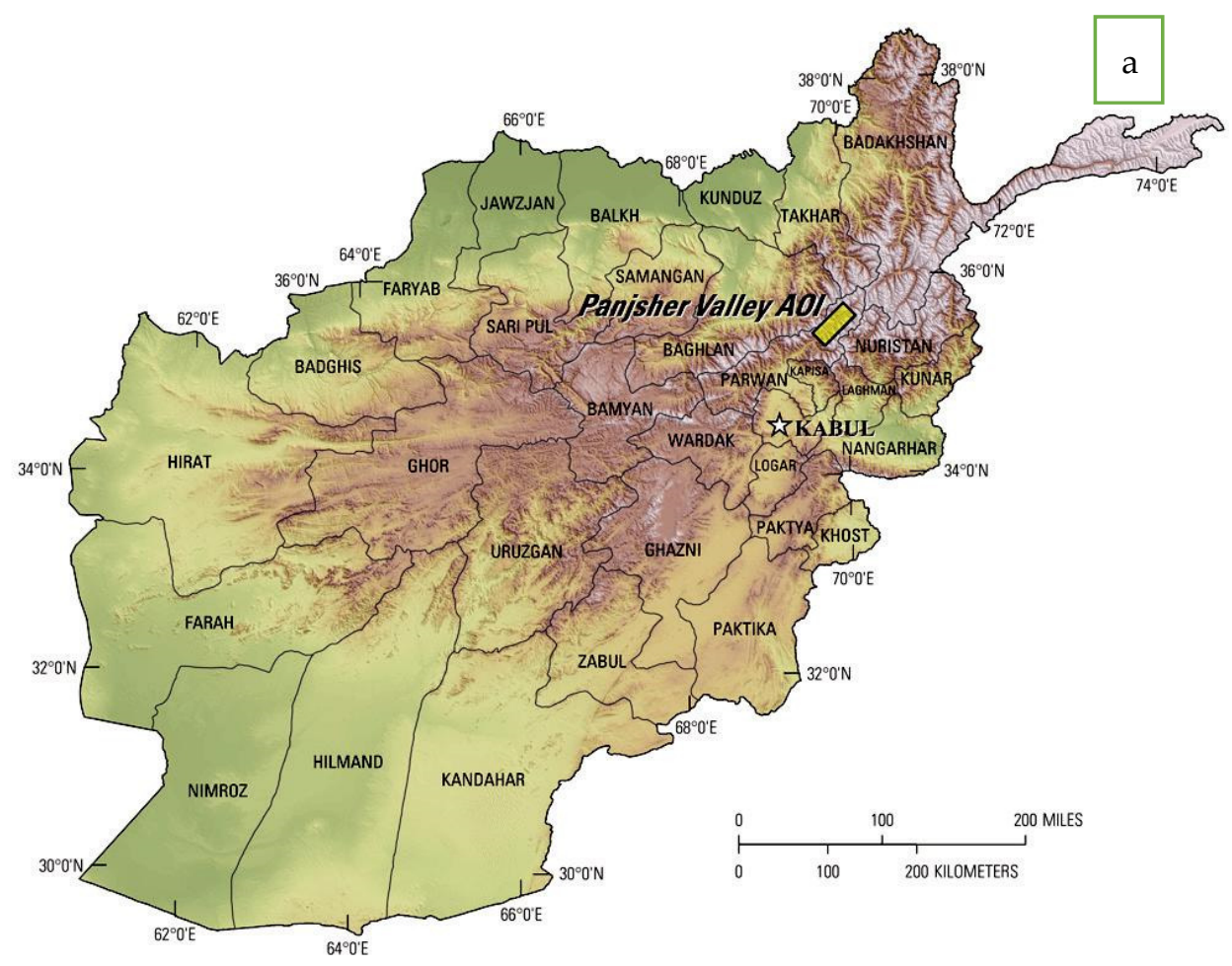



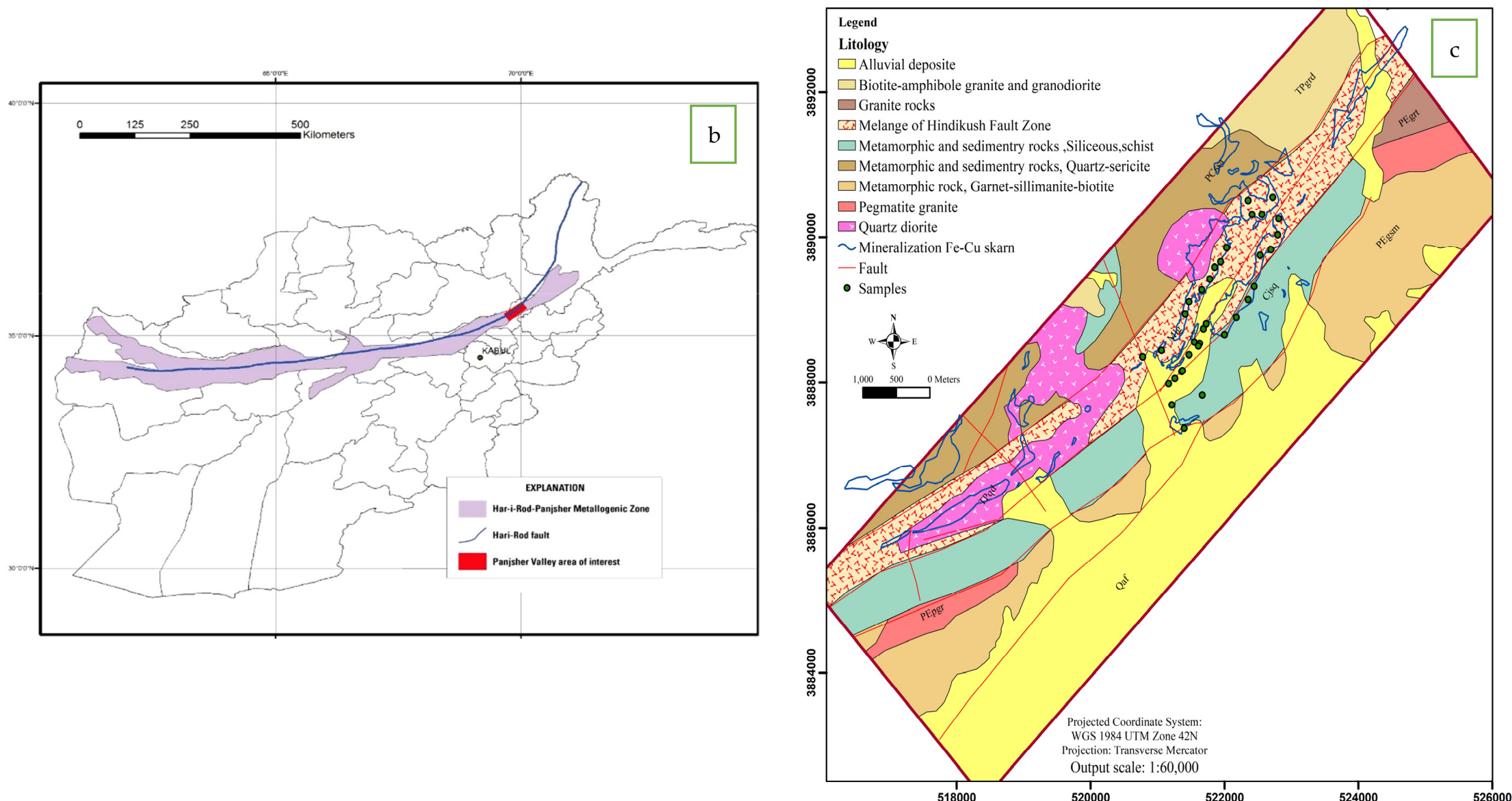

Figure 1. (a): Map of Afghanistan. Corresponding colors for major structural blocks, plutonic belts and faults are dark brown labels, blue labels, and black labels, respectively. Plutonic rocks are represented in red, other surrounding rocks in beige, and unconsolidated quaternary sediment in yellow (the area of interest is in red). (b): Area pertinent to iron and Skarn mineralization along with some of the main faults is determined on the map. Geologic and mineral map of AOI (prepared by USGS). (c): It should be noted that the scale of USGS map is 1:100,000, and this map was prepared by using old information (1975) and satellite images; therefore, it would not be very accurate because there are some differences between the field surveys' results and this map (host rocks for iron-copper mineralization are carbonate rocks [11]) 


\section{Material and Methods}

\subsection{Remote Sensing}

Obviously, the RS tool plays an important role in identification and distinction of altered zones and associated intrusions and hydrothermal fluids. In addition, due to multi-spectral and to cover the vast areas and mineralization zones associated with altered zones, satellite images have been widely used [12]. In this study, firstly, the presence of iron oxide and clay minerals in Panjsher iron deposits was detected by using Band Ratio (BR) and Principal Components Analysis (PCA) techniques. Furthermore, results derived from satellite image processing techniques for iron oxide map preparation were investigated based on obtained data from the field survey, petrographic study of polished sections, and geochemical analyses [13].

A False Color Composite (FCC) is an image processing technique that has appropriate results and is a common method to generate colorful images by using three different Bands: 7 (in red), 5 (in green) and 2 (in blue). Since Landsat 8 has more bands in the visible range and the ASTER has more bands in the short infrared range, their color combination can be used to identify iron oxide and hydroxide group minerals and alterations, respectively. The RGB color composite of OLI Band 651 sensors (Figure 2a) is an effective tool for identifying iron oxides and hydroxides. As can be seen, areas with iron oxides and hydroxides are displayed in red and orange colors, clay alterations and phyllite in beige.

OLI data possesses great capability for lithological mapping. A false color composite image of Bands 7 (in red), 5 (in green) and 2 (in blue) is generated by comparison of very high values for iron oxide-bearing areas.

The Band Ratio is one of the spectral techniques in which ratios are simply the division of one band by another band to create a spectral index. Band Ratios is used to enhance the spectral differences between bands and to reduce the effects of topography. Dividing one spectral band by another produces an image that provides relative band intensities. The Band Ratio image enhances the spectral differences between bands and can be useful when trying to discriminate between land cover types. For this reason, in this study, ASTER sensor images were used [14].

Since high values in band ratio $4 / 2$ is sensitive to a low concentration of ferric iron, this band is very effective not only to identify the charge transfer absorption of ferric iron oxides in the blue spectral region but also to highlight iron oxides of mafic regolith [15]. The white pixels in Figure $2 b$ display the ferric iron occurrence in the AOI.

PCA, which is mostly used in earth science, is a technique to maximize the showing of the differences between spectral bands and compacting resulted data as a new linear recombination of features to generate separate and independent bands [16]. In this work, PCA was utilized to highlight iron oxide zones. In this regard, Band 6 had the best compatibility with iron oxide among other designed Bands $(2,3,4,5$, and 7$)$. In Figure 2c, the white pixels showing iron-oxide-bearing zones. 

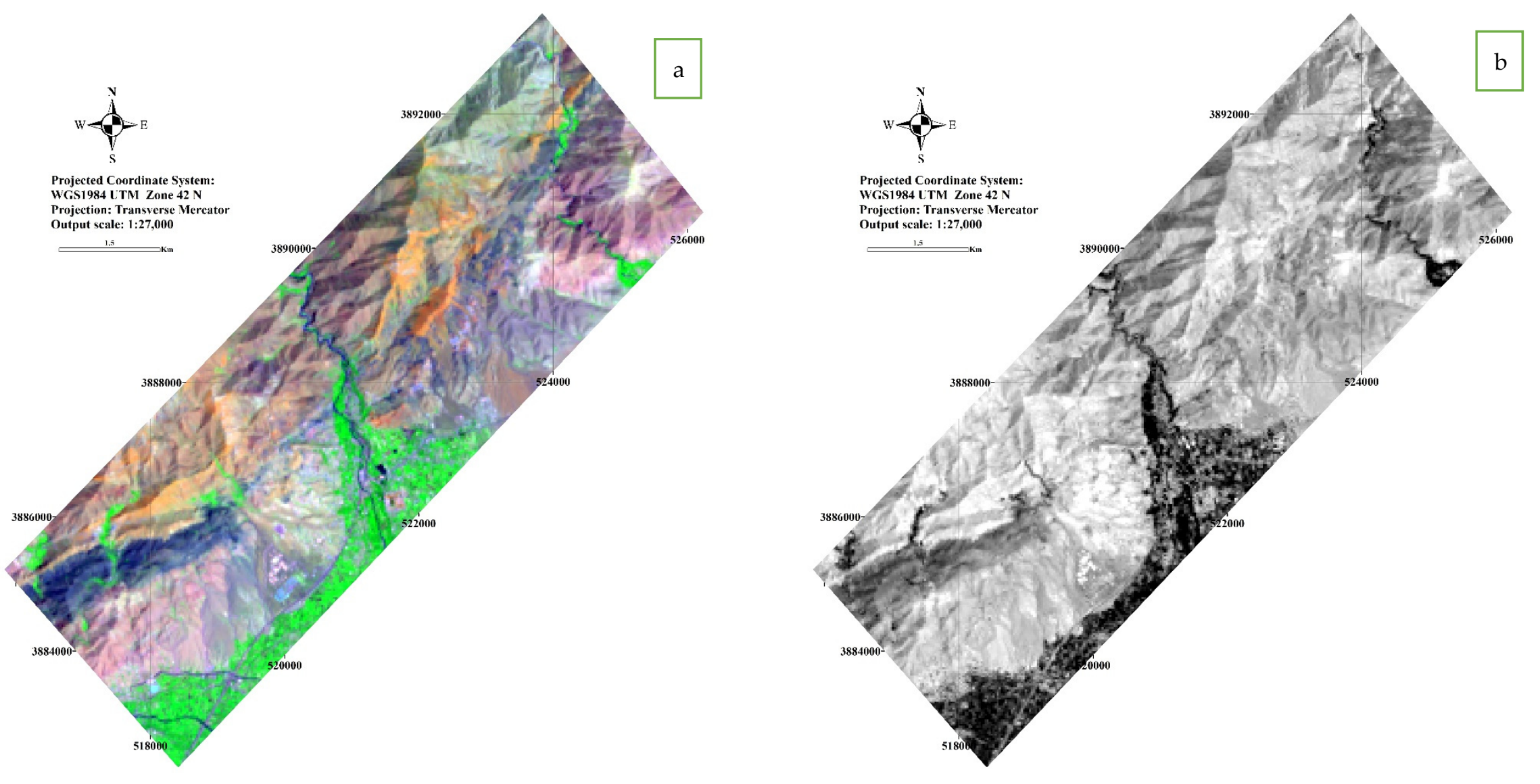


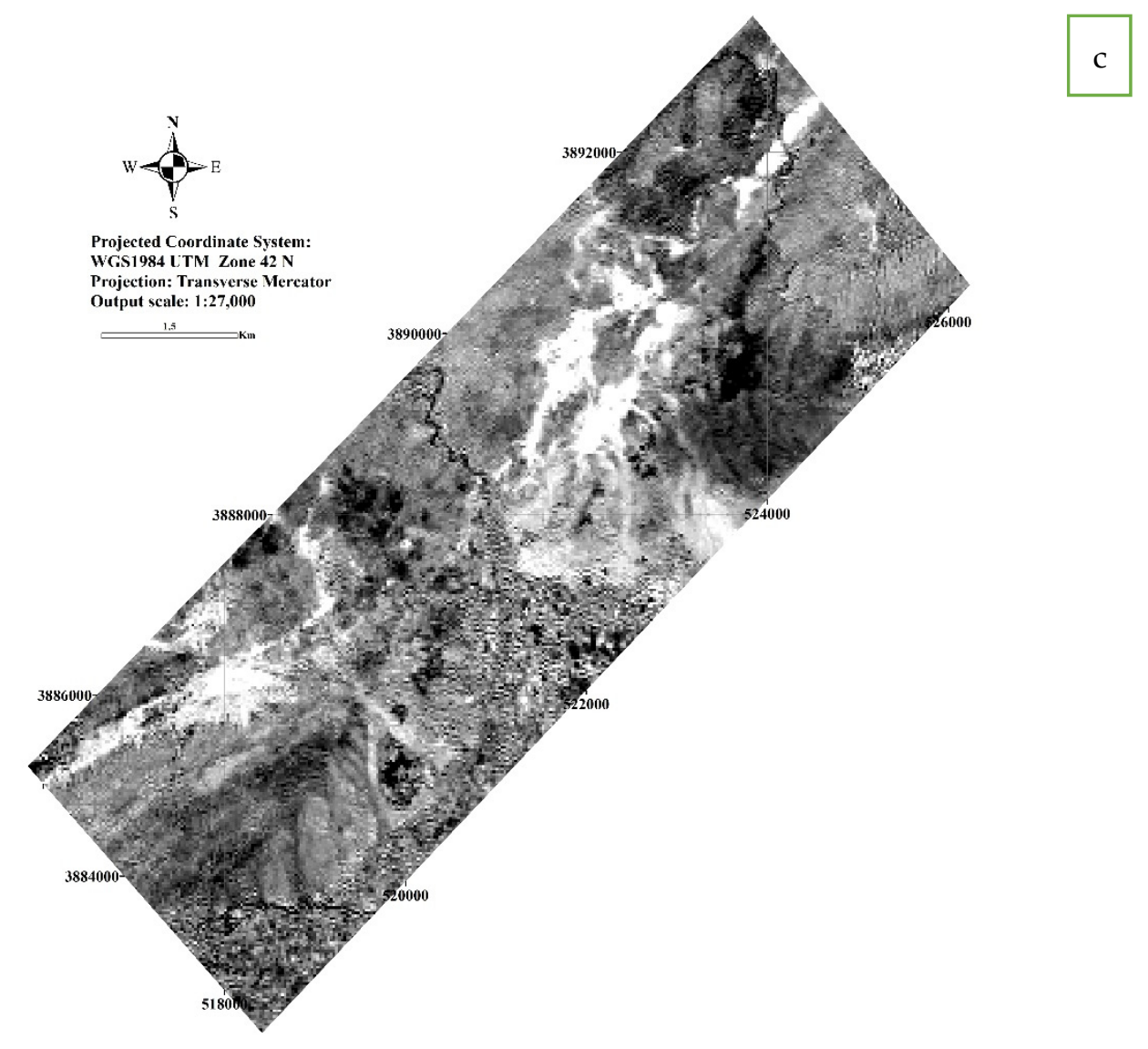

Figure 2. (a): Geological map resulted from color composition R:7, G:5, and B:2. The iron-bearing zones are marked with orange color. (b): The band ratio of $4 / 2$ used on ASTER sensor images shows iron oxide zones as white pixels. (c): PCA on Band 6 of ASTER sensor well displaying iron as white pixels.

\subsection{Mineralization}

The Panjsher Valley emerald, iron, and silver AOI lies within the Hari Rud-Panjsher Metallogenic Zone, which extends through the whole of Afghanistan from the western frontier eastward, and consists of a variety of mineral occurrence types and commodities, including barite, emerald, gold, iron, lead, manganese, mercury, silver, sulfur, and zinc [17].

According to geological evidence, geochemical studies, and polished section studies, there is a possibility of forming two types of mineralization in this AOI, including: a hematite-magnetite mineralization and $\mathrm{Cu}$-skarnization with a small amount of $\mathrm{Au}$. The former one was formed in the form of different-sized lenses within carbonate units and simultaneously with sedimentation (Figure 3a). These units contain a large amount of silver and iron content (up to $65 \%$ in weight of iron). These lenses mainly follow the stratification of their Protozoic host rock (up to 70 degrees to the northwest). Cuskarnization with $\mathrm{Au}$ was created by lying basalt-diabase lavas into carbonate units containing iron lenses, (Figure $3 b, c)$, which resulted in the generation of heat flow, and the crystallization of carbonate (marble) units and the mobilization of iron are relative to its previous formation zone. For this reason, the high and low level of Fe-skarnization in different zones is explicable. Additionally, these two types of mineralization are confirmed by less mobility of iron occurrence in crystalline carbonate lens units and no copper mineralization (chalcopyrite) occurrence, which are far from basalt-diabase occurrence. The skarnization system, as the main purpose of this work, will be explained in the following section.

Injection of basalt-diabase into carbonate rocks has caused isochemical metamorphism of the intrusive rocks and the formation of marble and hornfels. Crystallization during the cooling of magmatic flow has caused the evolution of the 
hydrothermal fluid phase and its penetration into carbonate entrapment rocks. The reaction of these fluids with primary metamorphic rocks caused extensive metasomatic metamorphism by the formation of anhydrous calc silicate minerals (pyroxene) and then hydrated calc silicate minerals (epidote and thermolite-actinolite), silicate (quartz), clay (chloride), oxidized (magnetite-hematite), sulfide (pyrite and chalcopyrite), and carbonate (calcite) (Figure 3d). In addition, in the contact of basalt-diabase units with carbonate rocks, hornfels is characterized by dense texture, intense silicification, the presence of high temperature minerals, such as pyroxene, as well as chalcopyrite, magnetite, and pyrite mineralization.

Due to the oxidation conditions prevailing in the region occurring after the formation of mineralization, magnetite has been converted to hematite, major copper sulfide ores to azurite, and finally, pyrite to oxide and iron hydroxides. Due to the formation of acidic solutions in atmospheric fluids, pyrite ore intensified leaching and weathering in the orebearing areas.

The petrography study of 4 polished sections of iron lenses and skarn zones was carried out to understand the nature of mineralization as well as to study the relationships between minerals. The geological and geochemical data were confirmed by the results of these studies. The corresponding mineral types for skarnization of chalcopyrite, pyrite, and magnetite ores and chalcocite, azurite, malachite, hematite, and other iron oxide ores are primitive and secondary, respectively (Figure $3 \mathrm{e}$ ).

Furthermore, petrography of the polished sections of the collected samples of iron lenses from AOI indicated the presence of hematite minerals along with primary pyrite voids, which are destroyed under the leaching process (Figure 3f).
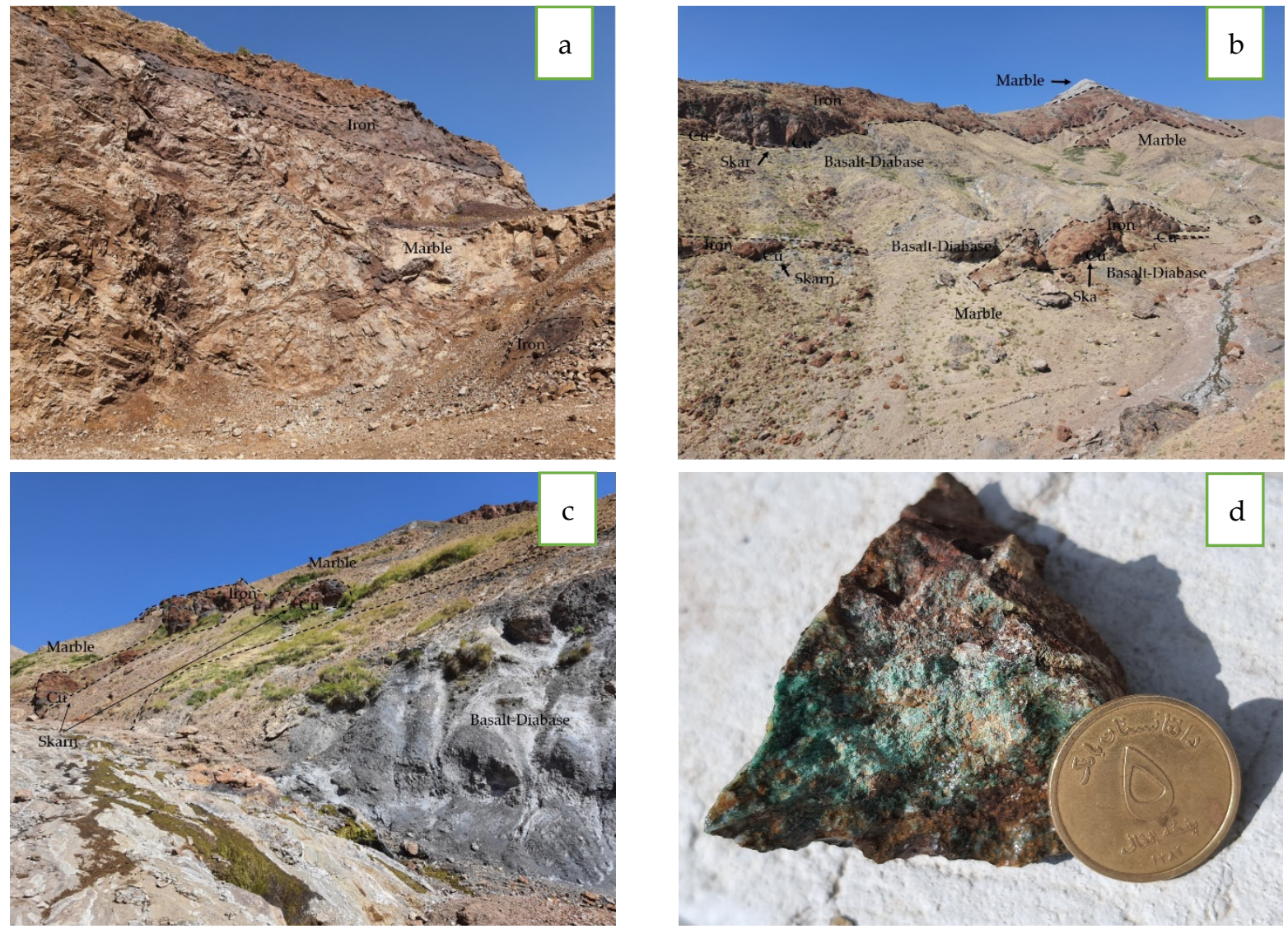

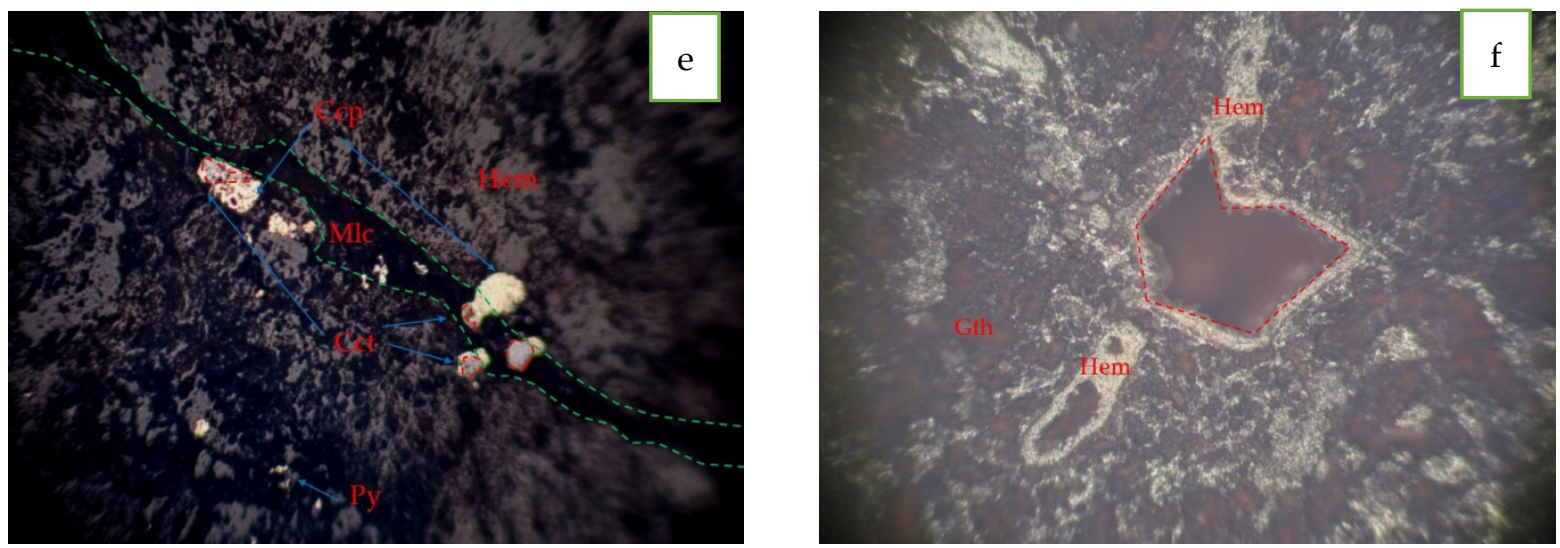

Figure 3. (a): The presence of hematite lenses inside the crystallized carbonate host rock. (b,c): In this image, iron lenses of different sizes are shown. Additionally, the conformability of basalt-diabase units with ferrous carbonate units has iron lenses of different sizes are shown. Additionally, the conformability of basalt-diabase units with ferrous carbonate units has led to the formation of copper-gold skarnization and mineralization (d): A collected sample from skarn zone by the presence of malachite, quartz, calcite, pyroxene, and hematite. (e): Prepared polishing section from skarn zone in which the presence of chalcopyrite (Ccp) and pyrite (Py) ores (as primary ores) and malachite (Mlc), chalcocite (Cct), and hematite $(\mathrm{Hem})$ are present. (f): This image belongs to the polishing section of iron ore in lenses enclosed in crystalline carbonate units. Hematite iron (Hem) with goethite (Gth) containing voids left from primary pyrite.

\subsection{Geochemistry}

To analyze the elements in the basic and skarn units, 30 samples were collected from skarn and iron lenses in the carbonate host rocks and basalt-diabase units. The samples were analyzed by a handheld XRF (Niton XL3t GOLDD+). Due to the large number of $\mathrm{XRF}$ analyses and its comparison with ICP-MS analysis data, the accuracy of the obtained data is confirmed by a factor of $90 \%$, and some results obtained are mentioned as follows:

- Silver in lenses containing iron is higher than the skarn zone. The correlation of Fe with $\mathrm{Ag}$ in iron lenses is above 0.9 .

- According to the correlation (Table 1), there is no positive correlation between the elements of samples collected from iron and skarn mineralization, and there is no good correlation between $\mathrm{Fe}$ and $\mathrm{Cu}$. The corresponding correlations between Fe and $\mathrm{Cu}$ for samples collected from skarn and iron lenses are 0.4 and -0.25 , respectively (Table 1).

- $\quad$ Some rock samples were collected from the AOI. The chemical analysis results of which were studied by considering of the diagrams using to distinguish between different iron deposits types. The results revealed that the polymetallic deposit in the AOI is in $\mathrm{Fe}-\mathrm{Cu}-(\mathrm{Au})$ skarn type mineralization [18] (Figure 4). 
Table 1. (a): Correlation table between elements in iron ore (Parwan-Panjsher AOI), which exists as lenses in crystallized carbonate rocks. As can be seen, there is a high correlation between $\mathrm{Fe}$ and $\mathrm{Ba}, \mathrm{Sn}, \mathrm{Ag}, \mathrm{Mo}, \mathrm{Nb}, \mathrm{Sr}$ and $\mathrm{W}$. (b): Correlation of elements in Skarn zone samples, which only shows the positive correlation between $\mathrm{Cu}$ and $\mathrm{W}$. In both graphs, there is no proper correlation between $\mathrm{Fe}$ and $\mathrm{Cu}$.

\begin{tabular}{|c|c|c|c|c|c|c|c|c|c|c|c|c|c|c|c|c|c|c|c|c|c|c|}
\hline$B a$ & 1 & & & & & & & & & & & & & & & & & & & & \multirow[b]{4}{*}{ a } & \\
\hline$S n$ & 0.76 & 1 & & & & & & & & & & & & & & & & & & & & \\
\hline$A g$ & 0.91 & 0.79 & 1 & & & & & & & & & & & & & & & & & & & \\
\hline$M o$ & 0.97 & 0.62 & 0.88 & 1 & & & & & & & & & & & & & & & & & & \\
\hline $\mathrm{Nb}$ & 0.85 & 0.41 & 0.71 & 0.92 & 1 & & & & & & & & & & & & & & & & & \\
\hline$S r$ & 0.97 & 0.75 & 0.91 & 0.95 & 0.79 & 1 & & & & & & & & & & & & & & & & \\
\hline As & -0.91 & -0.75 & -0.88 & -0.92 & -0.83 & -0.92 & 1 & & & & & & & & & & & & & & & \\
\hline $\mathrm{Pb}$ & -0.80 & -0.70 & -0.81 & -0.83 & -0.76 & -0.83 & 0.97 & 1 & & & & & & & & & & & & & & \\
\hline$W$ & 0.85 & 0.55 & 0.82 & 0.89 & 0.73 & 0.89 & -0.79 & -0.69 & 1 & & & & & & & & & & & & & \\
\hline $\mathrm{Zn}$ & 0.18 & -0.09 & -0.03 & 0.19 & 0.18 & 0.22 & -0.11 & -0.05 & 0.05 & 1 & & & & & & & & & & & & \\
\hline $\mathrm{Cu}$ & -0.18 & 0.04 & -0.07 & -0.26 & -0.16 & -0.27 & 0.18 & 0.19 & -0.29 & -0.57 & 1 & & & & & & & & & & & \\
\hline $\mathrm{Ni}$ & 0.26 & 0.23 & 0.15 & 0.26 & 0.36 & 0.22 & -0.33 & -0.41 & -0.14 & 0.44 & -0.22 & 1 & & & & & & & & & & \\
\hline $\mathrm{Fe}$ & 0.98 & 0.75 & 0.90 & 0.97 & 0.85 & 0.97 & -0.94 & -0.86 & 0.83 & 0.26 & -0.26 & 0.37 & 1 & & & & & & & & & \\
\hline$M n$ & 0.96 & 0.73 & 0.89 & 0.96 & 0.84 & 0.97 & -0.94 & -0.87 & 0.81 & 0.30 & -0.28 & 0.41 & 0.99 & 1 & & & & & & & & \\
\hline $\mathrm{Cr}$ & 0.93 & 0.74 & 0.82 & 0.85 & 0.72 & 0.90 & -0.78 & -0.65 & 0.66 & 0.39 & -0.14 & 0.42 & 0.92 & 0.91 & 1 & & & & & & & \\
\hline$V$ & 0.63 & 0.37 & 0.63 & 0.68 & 0.75 & 0.59 & -0.71 & -0.71 & 0.44 & 0.30 & -0.36 & 0.57 & 0.70 & 0.70 & 0.57 & 1 & & & & & & \\
\hline $\mathrm{Ca}$ & -0.99 & -0.73 & -0.89 & -0.97 & -0.87 & -0.97 & 0.93 & 0.83 & -0.84 & -0.24 & 0.19 & -0.29 & -0.99 & -0.97 & -0.92 & -0.67 & 1 & & & & & \\
\hline$K$ & 0.45 & 0.47 & 0.51 & 0.41 & 0.35 & 0.35 & -0.32 & -0.28 & 0.30 & -0.44 & 0.29 & 0.11 & 0.38 & 0.38 & 0.40 & 0.16 & -0.39 & 1 & & & & \\
\hline$A l$ & 0.73 & 0.71 & 0.74 & 0.62 & 0.41 & 0.74 & -0.64 & -0.51 & 0.59 & 0.36 & 0.01 & 0.07 & 0.73 & 0.72 & 0.82 & 0.38 & -0.75 & 0.18 & 1 & & & \\
\hline $\mathrm{Si}$ & -0.62 & -0.59 & -0.65 & -0.66 & -0.58 & -0.74 & 0.80 & 0.88 & -0.62 & -0.17 & 0.46 & -0.39 & -0.72 & -0.77 & -0.51 & -0.60 & 0.67 & -0.10 & -0.36 & 1 & & \\
\hline $\mathrm{Cl}$ & 0.79 & 0.57 & 0.76 & 0.81 & 0.77 & 0.72 & -0.74 & -0.69 & 0.69 & -0.27 & -0.04 & 0.24 & 0.75 & 0.73 & 0.61 & 0.51 & -0.74 & 0.78 & 0.26 & -0.49 & 1 & \\
\hline$S$ & -0.70 & -0.47 & -0.70 & -0.76 & -0.77 & -0.67 & 0.82 & 0.84 & -0.56 & -0.05 & 0.21 & -0.47 & -0.75 & -0.77 & -0.56 & -0.75 & 0.73 & -0.55 & -0.32 & 0.66 & -0.79 & 1 \\
\hline & $B a$ & $S n$ & $A g$ & Mo & $\mathrm{Nb}$ & $S r$ & As & $\mathrm{Pb}$ & $W$ & $\mathrm{Zn}$ & $\mathrm{Cu}$ & $\mathrm{Ni}$ & $\mathrm{Fe}$ & $M n$ & $\mathrm{Cr}$ & V & $\mathrm{Ca}$ & $K$ & $A l$ & $S i$ & $\mathrm{Cl}$ & $S$ \\
\hline
\end{tabular}




\begin{tabular}{|c|c|c|c|c|c|c|c|c|c|c|c|c|c|c|c|c|c|c|c|c|}
\hline $\mathrm{Ba}$ & 1 & & & & & & & & & & & & & & & & & & & \\
\hline $\mathrm{Sr}$ & 0.883 & 1 & & & & & & & & & & & & & & & & & & \\
\hline $\mathrm{Rb}$ & 0.64 & 0.673 & 1 & & & & & & & & & & & & & & & & & \\
\hline As & 0.159 & -0.1 & -0.36 & 1 & & & & & & & & & & & & & & & & \\
\hline $\mathrm{Pb}$ & 0.656 & 0.519 & 0.368 & 0.522 & 1 & & & & & & & & & & & & & & & \\
\hline W & 0.395 & 0.214 & $\begin{array}{l}-0.02 \\
\end{array}$ & 0.48 & 0.431 & 1 & & & & & & & & & & & & & & \\
\hline $\mathrm{Zn}$ & -0.53 & -0.52 & -0.53 & $\begin{array}{l}0.193 \\
\end{array}$ & -0.11 & -0.26 & 1 & & & & & & & & & & & & & \\
\hline $\mathrm{Cu}$ & 0.417 & 0.121 & 0.116 & 0.02 & 0.195 & 0.597 & -0.37 & 1 & & & & & & & & & & & & \\
\hline $\mathrm{Ni}$ & -0.37 & -0.45 & -0.6 & 0.331 & -0.34 & -0.13 & 0.639 & -0.1 & 1 & & & & & & & & & & & \\
\hline $\mathrm{Fe}$ & 0.092 & -0.05 & -0.42 & 0.409 & -0.12 & 0.522 & -0.14 & 0.403 & 0.356 & 1 & & & & & & & & & & \\
\hline $\mathrm{Mn}$ & -0.12 & -0.25 & -0.64 & 0.229 & -0.19 & 0.195 & 0.361 & 0.409 & 0.661 & 0.67 & 1 & & & & & & & & & \\
\hline $\mathrm{Cr}$ & 0.023 & 0.004 & 0.316 & 0.171 & 0.338 & 0.126 & 0.238 & -0.27 & -0.31 & -0.18 & -0.44 & 1 & & & & & & & & \\
\hline $\mathrm{V}$ & 0.257 & 0.449 & -0.12 & 0.068 & 0.079 & -0.05 & -0.08 & -0.24 & 0.145 & -0 & 0.188 & -0.56 & 1 & & & & & & & \\
\hline $\mathrm{Ti}$ & -0.05 & 0.057 & 0.139 & -0.4 & 0.044 & 0.263 & -0.21 & 0.258 & -0.56 & -0.26 & -0.11 & 0.049 & 0.036 & 1 & & & & & & \\
\hline $\mathrm{Ca}$ & 0.821 & 0.826 & 0.583 & -0.02 & 0.464 & 0.438 & -0.77 & 0.353 & -0.69 & 0.211 & -0.23 & 0.096 & 0.161 & 0.228 & 1 & & & & & \\
\hline $\mathrm{K}$ & 0.599 & 0.619 & 0.8 & -0.29 & 0.425 & 0.248 & -0.45 & 0.32 & -0.64 & -0.04 & -0.31 & 0.483 & -0.28 & 0.336 & 0.716 & 1 & & & & \\
\hline $\mathrm{Al}$ & 0.513 & 0.502 & 0.202 & -0.17 & -0.08 & 0.242 & -0.09 & 0.375 & 0.15 & 0.49 & 0.446 & -0.07 & 0.169 & -0.1 & 0.423 & 0.403 & 1 & & & \\
\hline $\mathrm{Si}$ & 0.366 & 0.488 & 0.107 & 0.157 & 0.135 & 0.217 & -0.11 & -0.01 & 0.141 & 0.542 & 0.345 & 0.08 & 0.352 & -0.06 & 0.433 & 0.391 & 0.613 & 1 & & \\
\hline $\mathrm{Cl}$ & -0.25 & -0.36 & 0.05 & -0.49 & -0.61 & -0.34 & -0.01 & 0.222 & 0.236 & -0.18 & -0.02 & -0.37 & -0.31 & -0.19 & -0.4 & -0.26 & 0.043 & -0.58 & 1 & \\
\hline \multirow[t]{2}{*}{$\mathrm{S}$} & -0.21 & -0.4 & -0.19 & 0.127 & 0.041 & 0.059 & 0.087 & 0.126 & -0.08 & -0.31 & -0.25 & -0.06 & -0.34 & -0.1 & -0.31 & -0.41 & -0.52 & -0.92 & 0.451 & 1 \\
\hline & $\mathrm{Ba}$ & $\mathrm{Sr}$ & $\mathrm{Rb}$ & As & $\mathrm{Pb}$ & W & $\mathrm{Zn}$ & $\mathrm{Cu}$ & $\mathrm{Ni}$ & $\mathrm{Fe}$ & $\mathrm{Mn}$ & $\mathrm{Cr}$ & $\mathrm{V}$ & $\mathrm{Ti}$ & $\mathrm{Ca}$ & $\mathrm{K}$ & $\mathrm{Al}$ & $\mathrm{Si}$ & $\mathrm{Cl}$ & $S$ \\
\hline
\end{tabular}



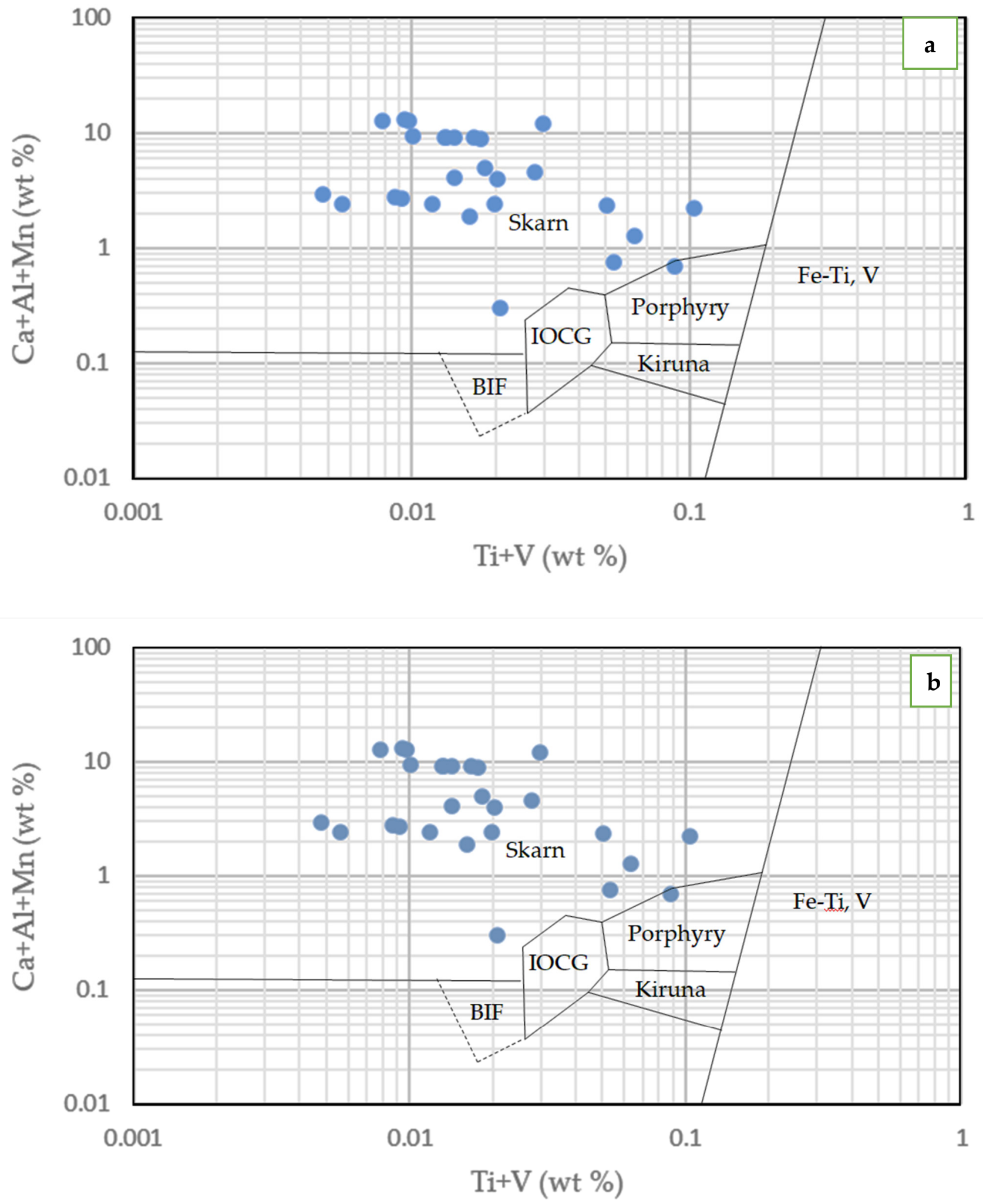

Figure 4. Location of iron-containing samples in the skarn zone of Parwan-Panjsher AOI. In both diagrams, the samples are in the skarn section. 


\section{Conclusions}

By using Remote Sensing processes on ASTER and ETM8 sensors, the best performance in this area was determined by PC6 Principal Component Analysis on the ASTER sensor.

According to geological, petrographic, and geochemical evidence, there are two types of mineralization in Parwan-Panjsher AOI. The first type is related to the mineralization of hematite-magnetite iron in small and large lenses with the crystalline limestone host rock, which has existed in the region for a long time. The second type of mineralization in the study area is copper-iron and gold skarnization, which is younger due to the conformability of basalt-diabase units with carbonate units. This division has been confirmed by the lack of proper correlation between elements of two different types. In fact, although in the samples collected from iron-containing lenses there is a high correlation between $\mathrm{Fe}$ and $\mathrm{Ba}, \mathrm{Sn}, \mathrm{Ag}$, $\mathrm{Mo}, \mathrm{Nb}, \mathrm{Sr}$, and $\mathrm{W}$, there is a positive correlation between $\mathrm{Cu}$ and $\mathrm{W}$. In both graphs, there is no proper correlation between $\mathrm{Fe}$ and $\mathrm{Cu}$.

Due to the high volume of hematite iron with low $\mathrm{FeO}$ content and crystalline carbonate units, this reserve can be used in cement production.

In order to find the copper-gold skarn and iron lens deposits in the AOI, accurate mapping of the AOI should be prepared to plan a systematic sampling network. Furthermore, geophysical operations (for the IP method for the skarn zone and the magnetometer method for the iron lenses to identify the magnetic part of the reserve) and subsurface drilling are recommended.

Institutional Review Board Statement: Not applicable.

Informed Consent Statement: Not applicable.

Data Availability Statement: 10.3390/iecms2021-09354 (registering DOI).

Acknowledge: We would like to express our gratitude to OMG/OGC who provided us with modern equipment, facilities, and monetary support for the accomplishment of this study in ParwanPanjsher AOI. Moreover, we would like to say thank you to all the kind people who have cooperated and helped us in relation to the field survey, sample collection, sample preparation, and so on.

Conflicts of Interest: The authors declare no conflict of interest.

\section{References}

1. Treloar, P.J.; Izatt, C.N. Tectonics of the Himalayan collision between the Indian plate and the Afghan block: A synthesis. Geol. Soc. Lond. Spec. Publ. 1993, 74, 69-87.

2. Molnar, P.; Tapponnier, P. The collision between India and Eurasia. Sci. Am. 1977, 236, 30-41.

3. King, T.V.; Kokaly, R.F.; Hoefen, T.M.; Johnson, M.R. Hyperspectral remote sensing data maps minerals in Afghanistan. Eos Trans. Am. Geophys. Union 2012, 93, 325-326.

4. Marjoribanks, R. Geological Methods in Mineral Exploration and Mining; Springer Science \& Business Media: Berlin/Heidelberg, Germany, 2010.

5. Hunt, G.R. Spectral signatures of particulate minerals in the visible and near infrared. Geophysics 1977, 42, 501-513.

6. Malistani, H. Hajigak Iron Ore Deposit; ResearchGate: Berlin, Germany, 2011.

7. Risen, J. US identifies vast mineral riches in Afghanistan. New York Times, 13 June 2010.

8. Abdullah, S.; Chmyriov, V.; Dronov, V. Geology and Mineral Resources of Afghanistan; British Geological Survey: Nottingham, $\mathrm{UK}, 2008$.

9. Azizi, M.; Saibi, H.; Cooper, G. Mineral and structural mapping of the Aynak-Logar Valley (eastern Afghanistan) from hyperspectral remote sensing data and aeromagnetic data. Arab. J. Geosci. 2015, 8, 10911-10918.

10. Abdullah, S.; Chmyriov, V.; Stazhilo-Alekseev, K.; Dronov, V.; Gannan, P.; Rossovskiy, L.; Kafarskiy, A.K.; Malyarov, E. Mineral resources of Afghanistan: Kabul; Republic of Afghanistan Geological and Mineral Survey: Kabul, Afghanistan, 1977.

11. Stettner, N.E.K.W.R.; Masonic, L.M.; Shields, D.A. Geologic and Mineral Map (Modified from the 1975 Original Map Compilation by A.S. Shadchinev and others) and Hyperspectral Surface Material Maps of the Chorband, Salang, and Panjsher River Basins; Kapisa, Panjsher, Parwan, and Baghlan Provinces, Afghanistan; U.S. Geological Survey: Reston, VA, USA, 2020. 
12. Khalaj, M. Investigation and their Relationship of copper mineralizations of ChahMousa, Derakhshanieh and Qollehsoukhteh area with structural lineaments based on geochemistry, alteration and fluid inclusion in the south of Damghan, In Proceedings of the 7th conference of the Iranian Economic Geological Society, Damghan University, Damghan, Iran, 9-10 September2015.

13. Rowan, L.C.; Kingston, M.J.; Crowley, J.K. Spectral reflectance of carbonatites and related alkalic igneous rocks; selected samples from four North American localities. Econ. Geol. 1986, 81, 857-871.

14. Gabr, S.S.; Hassan, S.M.; Sadek, M.F. Prospecting for new gold-bearing alteration zones at El-Hoteib area, South Eastern Desert, Egypt, using remote sensing data analysis. Ore Geol. Rev. 2015, 71, 1-13.

15. Ducart, D.F.; Silva, A.M.; Toledo, C.L.B.; Assis, L.M.D. Mapping iron oxides with Landsat-8/OLI and EO-1/Hyperion imagery from the Serra Norte iron deposits in the Carajás Mineral Province, Brazil. Braz. J. Geol. 2016, 46, 331-349.

16. Ranjbar, H.; Honarmand, M.; Moezifar, Z. Application of the Crosta technique for porphyry copper alteration mapping, using ETM+ data in the southern part of the Iranian volcanic sedimentary belt. J. Asian Earth Sci. 2004, 24, $237-243$.

17. Peters, S.G.; Ludington, S.D.; Orris, G.J.; Sutphin, D.M.; Bliss, J.D.; Rytuba, J.J.; Bawiec, W.J. Preliminary Non-Fuel Mineral Resource Assessment of Afghanistan 2007; US Geological Survey Open-File Report; United States Geological Survey: Reston, VA, USA, 2007; p. 1214.

18. Dupuis, C.; Beaudoin, G. Discriminant diagrams for iron oxide trace element fingerprinting of mineral deposit types. Miner. Depos. 2011, 46, 319-335. 